\title{
Kinetic Spectrophotometric Determination of Trace Amounts of Iodide in Food Samples
}

\author{
M. Reza ShIShehbore, ${ }^{\dagger}$ Ali SheIBAnI, and Roohollah Jokar \\ Department of Chemistry, Islamic Azad University, Yazd Branch, P. O. Box 89195-155, Yazd, Iran
}

\begin{abstract}
A simple, selective and sensitive kinetic method has been developed for the determination of trace amounts of iodide. This method is based on a catalytic effect of iodide on the reaction between Janus Green and bromate in acidic media. Trace amounts of iodide increase the rate of a reaction that is monitored spectrophotometrically at $618 \mathrm{~nm}$ by a fixed-time method at $30 \mathrm{~s}$. Effective parameters on the reaction rate, such as the concentration of reactants, temperature and reaction time, were investigated and the optimum conditions were obtained $\left(6.0 \times 10^{-2} \mathrm{~mol} \mathrm{~L}^{-1}\right.$ of sulfuric acid, $2.50 \times 10^{-5} \mathrm{~mol} \mathrm{~L}^{-1}$ of Janus Green, $1.75 \times 10^{-2} \mathrm{~mol} \mathrm{~L}^{-1}$ of bromate, $30^{\circ} \mathrm{C}$ and $180 \mathrm{~s}$ ). The calibration curve was linear between $0.5-190.0 \mu \mathrm{g} \mathrm{L}-1$ of iodide, and the relative standard deviations $(n=5)$ for 10.0 and $100.0 \mu \mathrm{g} \mathrm{L} \mathrm{L}^{-1}$ of iodide were 1.2 and $1.8 \%$, respectively. The limit of detection was $0.12 \mu \mathrm{g} \mathrm{L}-1$ of iodide concentration. The effects of various substances upon the reaction rate were determined for assigning the selectivity of the method. The proposed method was successfully applied to the determination of iodide in food samples. The new developed method was found to have fairly good selectivity, sensitivity, simplicity and rapidity.
\end{abstract}

(Received September 24, 2009; Accepted November 24, 2009; Published April 10, 2010)

\section{Introduction}

Iodine is a highly volatile element, and is emitted into troposphere by natural anthropogenic sources, such as burning coal, smelting ores and evaporation of soil iodine. This element is an essential nutrient in the human diet, which is naturally found in or added as a supplement to many food samples. ${ }^{1}$ The daily requirement of iodide is $0.14 \mathrm{mg}$ for adult men and $0.10 \mathrm{mg}$ for adult women, ${ }^{2}$ which is normally met by well-balanced diets and drinking water. ${ }^{3,4}$ The absence of this element in the diet may result in serious biochemical disturbances, i.e. myxedema and cretinism. Iodide deficiency causes goiter disease, and its excessive intake may contribute to thyrotoxicosis. ${ }^{5}$ Therefore, the determination of iodide in food samples is important with respect to environmental and biochemical aspects.

Several sensitive methods used for determination of trace amounts of iodide in various samples include inductively coupled plasma-atomic emission spectrometry (ICP-AES), ${ }^{6,7}$ inductively coupled plasma-mass spectrometry (ICP-MS), neutron activation analysis (NAA), ${ }^{10,11}$ ion chromatography (IC), ${ }^{12-14}$ molecular absorption spectrometry ${ }^{15}$ and an optical redox sensor. ${ }^{16}$ These methods are expensive and require preconcentration $^{6-14}$ and/or separation ${ }^{10-14}$ of the samples or special instruments. ${ }^{6-11,15,16}$ However, we need a simple, sensitive and selective method that does not require any excess process of foods in order to analyze a large number of samples.

Various reports on iodide determination by spectrophotometric methods are available. ${ }^{17-38}$ The $\mathrm{NO}_{2}{ }^{-}[\mathrm{Fe}(\mathrm{SCN})]^{2+}$ reaction has been adopted as a standard method for iodide determination in

$\dagger$ To whom correspondence should be addressed.

E-mail: shishehbor47@gmail.com natural and waste water samples as well as in food and biological samples. ${ }^{39}$

In this paper, a kinetic spectrophotometric method is proposed based on a catalytic effect of iodide on the reaction between Janus Green and bromate in acidic media. The reaction was followed spectrophotometrically by monitoring the decrease in the absorbance of Janus Green at $618 \mathrm{~nm}$ with a fixed-time method. The proposed method is suitable for the determination of iodide in food samples.

\section{Experimental}

\section{Reagents and chemicals}

Analytical-grade chemicals and redistilled water were used. First, $100 \mathrm{~mL}$ of an iodide stock solution of $100.0 \mathrm{mg} \mathrm{L}^{-1}$ (as iodide stock solution) was prepared by dissolving $0.0131 \mathrm{~g}$ of potassium iodide (Merck) in water and diluting to $100 \mathrm{~mL}$ in a volumetric flask. Working solutions were prepared by appropriate dilution with water. A solution of Janus Green $\left(1.0 \times 10^{-3} \mathrm{~mol} \mathrm{~L}^{-1}\right)$ was prepared by dissolving $0.0511 \mathrm{~g}$ of it in water, and then diluting to $100 \mathrm{~mL}$ in a volumetric flask. A sulfuric acid solution $\left(2.0 \mathrm{~mol} \mathrm{~L}^{-1}\right)$ was prepared by diluting $54.35 \mathrm{~mL}$ of conc. sulfuric acid $\left(a=98 \%, d=1.84 \mathrm{~kg} \mathrm{~L}^{-1}\right)$ to $500 \mathrm{~mL}$; a $0.25 \mathrm{~mol} \mathrm{~L}^{-1}$ of potassium bromate stock solution was subsequently prepared by dissolving $10.4380 \mathrm{~g}$ of $\mathrm{KBrO}_{3}$ (Merck) in water and diluting to $250 \mathrm{~mL}$ in a volumetric flask.

\section{Apparatus}

A Shimadzu spectrophotometer (160-A, Japan) with 1-cm glass cell was used to measure the absorbance. A thermostated water bath (Heidolph, Germany) was used to keep the temperature of all solutions at the working temperature $\left(25 \pm 0.1{ }^{\circ} \mathrm{C}\right)$. A stop-watch was used to record the reaction time. 


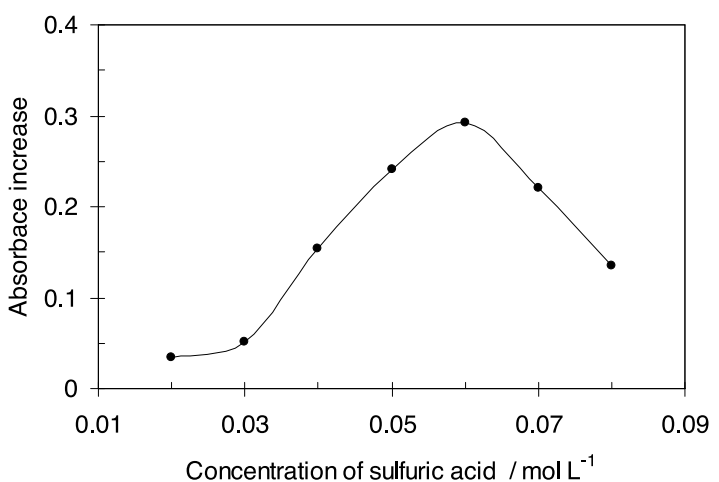

Fig. 1 Effect of the sulfuric acid concentration on the reaction rate: Janus Green, $0.25 \mathrm{~mL}$ of $2.5 \times 10^{-5} \mathrm{~mol} \mathrm{~L}^{-1}$; iodide, $10.0 \mu \mathrm{g} \mathrm{L}^{-1}$; bromate, $0.4 \mathrm{~mL}$ of $0.25 \mathrm{~mol} \mathrm{~L}^{-1}$; temperature, $25^{\circ} \mathrm{C}$; time, $5.0 \mathrm{~min}$.

\section{Recommended procedure}

After initial spectrophotometric kinetic studies of the reaction, the reagent concentrations (except the catalyst) were judiciously chosen for the analytical procedure. To a series of $10 \mathrm{~mL}$ calibrated flasks, $0.25 \mathrm{~mL}$ of $2.0 \mathrm{~mol} \mathrm{~L}^{-1}$ sulfuric acid, $0.25 \mathrm{~mL}$ of a $1.0 \times 10^{-3} \mathrm{~mol} \mathrm{~L}^{-1}$ Janus Green solution and $1.0 \mathrm{~mL}$ of $0.1 \mathrm{mg} \mathrm{L}^{-1}$ of iodide were added. Then, $0.4 \mathrm{~mL}$ of $0.25 \mathrm{~mol} \mathrm{~L}^{-1}$ bromate solution was added and the solution diluted to the mark with redistilled water. A time measurement started just after adding the last drop of the oxidant solution. After thorough mixing, a portion of this solution was transferred to a glass cell, and the absorbance was measured against water at $618 \mathrm{~nm}$ and $25^{\circ} \mathrm{C}$ for fixed times of 0.5 and $5.0 \mathrm{~min}$. The measurements were repeated in the absence of iodide to obtain the value for the uncatalyzed reaction as the absorbance of the blank. The absorbance changes of the catalyzed and uncatalyzed reactions were labeled $\Delta A_{\mathrm{c}}$ and $\Delta A_{\mathrm{u}}$, respectively. The difference in the absorbance $(\Delta A)$ was considered as the response.

\section{Procedure for food sample preparation}

Food samples were subjected to an alkaline ashing process to decompose any organic matter and to convert iodine organically bound to the catalytically active inorganic form. During an ashing process, ultrasonication was performed so as to minimize the adsorption of iodide. ${ }^{33}$ For treating food samples, several tubes were simultaneously run along with a blank, as follows. We accurately transfered $0.70-1.00 \mathrm{~g}$ of a homogenized (finely blended) sample to a $25 \times 150 \mathrm{~mm}$ Pyrex tube. To decompose nitrite, $2 \mathrm{~mL}$ of $3 \%$ sulfamic acid was added and placed in an ultrasonic bath for $10 \mathrm{~min}$. Then, $1 \mathrm{~mL}$ of a $2 \mathrm{~mol} \mathrm{~L}^{-1} \mathrm{KOH}$ solution was added, followed by $1 \mathrm{~mL}$ of a $10 \% \mathrm{ZnSO}_{4}$ solution. These were mixed well and heated at $150^{\circ} \mathrm{C}$ for $30 \mathrm{~min}$, after which the temperature rose to $500^{\circ} \mathrm{C}$ and was maintained for $2 \mathrm{~h}$. We then cooled the tube, dissolved the formed iodide in about $10 \mathrm{~mL}$ of water, and centrifuged at $3000 \mathrm{rpm}$ for $3 \mathrm{~min}$ to separate the extract from carbonaceous matter. The formed extract was decanted into a $25-\mathrm{mL}$ calibrated flask, added further $10 \mathrm{~mL}$ of water, and repeated the dissolution, centrifugation, and decantation steps. The combined extracts were diluted to the mark in a calibrated flask. ${ }^{33,40}$

\section{Results and Discussion}

Janus Green is a basic dye of a mono-azo group that can be

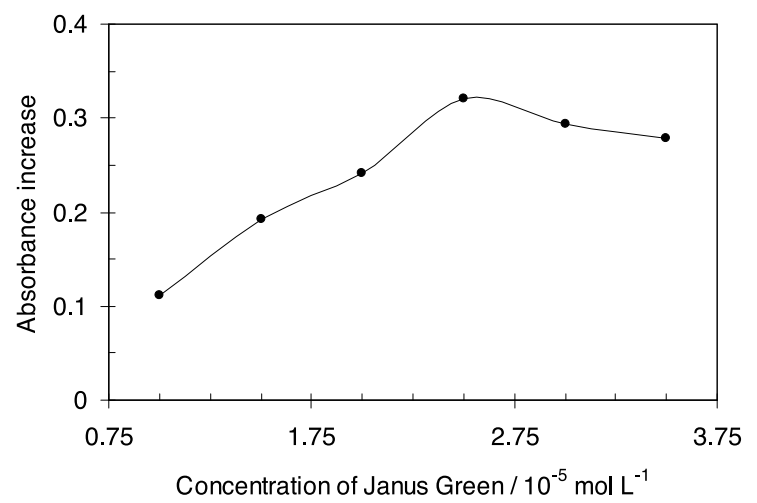

Fig. 2 Effect of the Janus Green concentration on the reaction rate: sulfuric acid, $0.3 \mathrm{~mL}$ of $2.0 \mathrm{~mol} \mathrm{~L}^{-1}$; iodide, $10.0 \mu \mathrm{g} \mathrm{L}^{-1}$; bromate, $0.4 \mathrm{~mL}$ of $0.25 \mathrm{~mol} \mathrm{~L}^{-1}$; temperature, $25^{\circ} \mathrm{C}$; time, $5.0 \mathrm{~min}$.

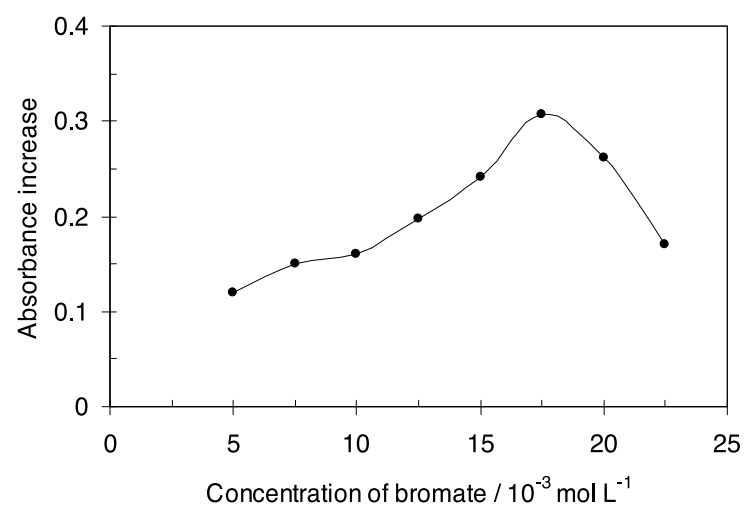

Fig. 3 Effect of the bromate concentration on the reaction rate: sulfuric acid, $0.3 \mathrm{ml}$ of $2.0 \mathrm{~mol} \mathrm{~L}^{-1}$; Janus Green, $0.25 \mathrm{~mL}$ of $1.0 \times 10^{-3} \mathrm{~mol} \mathrm{~L}-1$; iodide, $10.0 \mu \mathrm{g} \mathrm{L}^{-1}$; temperature, $25^{\circ} \mathrm{C}$; time, $5.0 \mathrm{~min}$.

oxidized by strong oxidizing agents, such as bromate in an acidic media at a slow reaction to produce a colorless oxidized form. ${ }^{41,42}$ It was used as an indicator for the catalytic determination of formaldehyde ${ }^{42}$ and silver, ${ }^{43}$ and also for the catalytic determination of iodide.

The effect of such parameters as the reagent concentration, temperature and time on the reaction rate was studied based on a fixed-time method to obtain the best sensitivity, and to find the optimum conditions. Under these conditions, a calibration curve was constructed by plotting $\Delta A=\Delta A_{\mathrm{c}}-\Delta A_{\mathrm{u}}$ versus the iodide concentration.

\section{Effect of the reagents concentration}

The effects of the sulfuric acid concentration on the catalyzed and uncatalyzed reactions were studied over the range of 0.02 to $0.08 \mathrm{~mol} \mathrm{~L}^{-1}$. As shown in Fig. 1, the reaction rate increased with increasing sulfuric acid concentration up to $0.06 \mathrm{~mol} \mathrm{~L}^{-1}$, whereas at higher concentrations the rate of the reaction decreased. Therefore, a $0.06 \mathrm{~mol} \mathrm{~L}^{-1}$ sulfuric acid solution was used for a further study.

The effect of the Janus Green concentration on the reaction rate was studied in the range of $1.0 \times 10^{-5}$ to $3.5 \times 10^{-5} \mathrm{~mol} \mathrm{~L}^{-1}$. As shown in Fig. 2, by increasing the Janus Green concentration up to $2.5 \times 10^{-5} \mathrm{~mol} \mathrm{~L}^{-1}$, the rate of the catalyzed reaction increased. Therefore, $2.5 \times 10^{-5} \mathrm{~mol} \mathrm{~L}^{-1}$ Janus Green was 
chosen as the optimum value.

The effect of the bromate concentration on the rate of the catalyzed oxidation of Janus Green was studied in the range of $5.0 \times 10^{-3}$ to $2.25 \times 10^{-2} \mathrm{~mol} \mathrm{~L}^{-1}$ of bromate. As shown in Fig. 3, under the optimum concentrations of $\mathrm{H}_{2} \mathrm{SO}_{4}$ and Janus Green, the rate of the reaction was increased up to $1.75 \times 10^{-2} \mathrm{~mol} \mathrm{~L}^{-1}$ of bromate, which was selected as being the optimum concentration of the oxidant.

\section{Effect of the ionic strength, temperature and reaction time}

The effect of the ionic strength was studied by using a potassium nitrate solution $\left(3.0 \mathrm{~mol} \mathrm{~L} \mathrm{~L}^{-1}\right)$ under the optimum reagent concentration. The results showed that the sensitivity dose not depend on the ionic strength up to $0.5 \mathrm{M}$ of the potassium nitrate concentration, whereas greater amounts of it

Table 1 Tolerance limit for foreign species on the determination of $100.0 \mu \mathrm{g} \mathrm{L}^{-1}$ of iodide

\begin{tabular}{lc}
\hline \multicolumn{1}{c}{ Foreign species } & Tolerance limit \\
\hline Glucose, saccarose, fructose, EDTA, methanol, & 1000 \\
ethanol, sulfamic acid, citric acid & \\
Ascorbic acid, oxalic acid & 950 \\
Benzaldehyde, acetaldehyde & 400 \\
Formaldehyde & 50 \\
$\mathrm{Li}^{+}, \mathrm{Na}^{+}, \mathrm{K}^{+}, \mathrm{Mg}^{2+}, \mathrm{Al}^{3+}, \mathrm{NH}_{4}^{+}, \mathrm{Co}^{2+}, \mathrm{Cd}^{2+}$ & 1000 \\
$\mathrm{Ca}^{2+a}$ & 850 \\
$\mathrm{Fe}^{3+a}, \mathrm{As}^{3+a}, \mathrm{Cr}^{3+a}$ & 600 \\
$\mathrm{NO}_{3}{ }^{-}, \mathrm{SO}_{4}^{2-}, \mathrm{CO}_{3}^{2-}, \mathrm{CH}_{3} \mathrm{COO}^{-}, \mathrm{PO}_{4}{ }^{3-}, \mathrm{HPO}_{4}^{2-}$, & 1000 \\
$\mathrm{H}_{2} \mathrm{PO}_{4}^{-}, \mathrm{F}^{-}, \mathrm{NO}_{2}{ }^{-b}$ & \\
$\mathrm{Cl}^{-}$ & 15 \\
$\mathrm{VO}_{3}^{-}$ & 2 \\
$\mathrm{Br}^{-}$ & 1 \\
\hline
\end{tabular}

a. After masking with $2 \mathrm{~mL}$ of $2 \%$ EDTA solution.

b. After addition $2 \mathrm{~mL}$ of $3 \%$ sulfamic acid solution. decreased the sensitivity. This may be attributed to the absorption behavior of Janus Green under this condition. At higher concentrations of potassium nitrate, the close proximity of ions to Janus Green alters the molar absorptivity of dye due to electrostatic interactions.

The effect of the temperature on the reaction rate was studied in the range of 15 to $40^{\circ} \mathrm{C}$ in the optimum concentrations of the reagents. Increasing the temperature up to $30^{\circ} \mathrm{C}$ caused an increase in the sensitivity, whereas at higher temperatures it decreased. Thus, $30^{\circ} \mathrm{C}$ was selected as being the optimum temperature.

The optimum time was found by measuring the change in the absorbance during $0.5-5.0 \mathrm{~min}$. The reaction rate increased for up to $180 \mathrm{~s}$, and for longer times the rate was almost constant. Therefore, $180 \mathrm{~s}$ was selected for further study.

\section{Analytical parameters}

After optimizing the reaction conditions, a calibration curve was obtained over the range of $0.5-190.0 \mu \mathrm{g} \mathrm{L}^{-1}$ of iodide. An analysis of the data gave the following regression equation: $\Delta A=0.0072\left[\mathrm{I}^{-}\right]+0.2529 \quad\left(R^{2}=0.9995\right)$, where $\Delta A$ is the difference in the absorbance between the blank and the sample, $\left[\mathrm{I}^{-}\right]$is the iodide concentration in $\mu \mathrm{g} \mathrm{L}^{-1}$ and $R^{2}$ is the correlation coefficient. Moreover, data analyses of the calibration curve in the range of $0.5-10.0 \mu \mathrm{g} \mathrm{L}^{-1}$ gave the regression equation: $\Delta A=0.004\left[\mathrm{I}^{-}\right]+0.2703 \quad\left(R^{2}=0.9959\right)$ for iodide. This correlation coefficient shows results at low concentrations that are in good agreement. The detection limit $\left(3 S_{\mathrm{b}} / m\right)$ was $0.12 \mu \mathrm{g} \mathrm{L}^{-1}$ iodide. The relative standard deviations $(n=5)$ were 1.21 and $1.80 \%$ for 10.0 and $100.0 \mu \mathrm{g} \mathrm{L}^{-1}$ iodide, respectively.

\section{Interference studies}

The effect of various substances on the determination of $100.0 \mu \mathrm{g} \mathrm{L}^{-1}$ of iodide was studied; the results are given in Table 1. The tolerance was defined as the concentration of added substance causing a change of less than $5.4 \%$ in the rate

Table 2 Determination of iodide in food samples

\begin{tabular}{|c|c|c|c|c|c|c|c|}
\hline \multicolumn{2}{|c|}{ Sample $^{\mathrm{a}}$} & \multicolumn{2}{|r|}{ Iodide $^{b}$} & \multirow{2}{*}{$\mathrm{RSD}, \%$} & \multirow{2}{*}{ Recovery, $\%$} & \multirow{2}{*}{$\begin{array}{c}\mathrm{AOAC}^{39} \\
\text { Found } \pm \mathrm{SD}(n=5)\end{array}$} & \multirow{2}{*}{ Recovery, $\%$} \\
\hline Type & Weight/g & Added & Found $\pm \operatorname{SD}(n=5)$ & & & & \\
\hline \multirow[t]{2}{*}{ Milk } & 0.617 & - & $34.35 \pm 0.50$ & 1.5 & - & $34.96 \pm 0.37$ & \\
\hline & & 100 & $134.98 \pm 1.39$ & 1.0 & 100.6 & $135.62 \pm 1.49$ & 100.7 \\
\hline \multirow[t]{2}{*}{ Butter } & 0.598 & - & $56.45 \pm 0.49$ & 0.9 & - & $55.78 \pm 0.32$ & \\
\hline & & 100 & $156.18 \pm 1.44$ & 0.9 & 99.0 & $155.71 \pm 1.51$ & 99.9 \\
\hline \multirow[t]{2}{*}{ Egg (hen) } & 0.724 & - & $78.32 \pm 0.91$ & 1.2 & - & $77.69 \pm 0.82$ & \\
\hline & & 100 & $177.09 \pm 1.54$ & 0.87 & 98.8 & $177.84 \pm 1.51$ & 100.1 \\
\hline \multirow[t]{2}{*}{ Beef } & 0.968 & - & $222.75 \pm 4.19$ & 1.9 & - & $220.89 \pm 3.71$ & \\
\hline & & 100 & $323.65 \pm 3.75$ & 1.2 & 100.9 & $320.79 \pm 3.59$ & 99.9 \\
\hline \multirow[t]{2}{*}{ Carrot $^{\mathrm{c}}$} & 0.761 & - & $38.47 \pm 0.56$ & 1.5 & - & $39.21 \pm 0.56$ & \\
\hline & & 100 & $139.31 \pm 1.69$ & 1.2 & 100.8 & $139.02 \pm 1.28$ & 99.8 \\
\hline \multirow[t]{2}{*}{ Potato $^{\mathrm{c}}$} & 0.689 & - & $44.63 \pm 0.58$ & 1.3 & - & $43.68 \pm 0.57$ & \\
\hline & & 100 & $142.91 \pm 1.71$ & 1.2 & 98.3 & $145.21 \pm 1.45$ & 101.5 \\
\hline \multirow[t]{2}{*}{ Tomato $^{c}$} & 0.926 & - & $14.83 \pm 0.25$ & 1.7 & - & $14.75 \pm 0.22$ & \\
\hline & & 100 & $116.31 \pm 1.72$ & 1.5 & 101.5 & $115.38 \pm 1.16$ & 100.6 \\
\hline \multirow[t]{2}{*}{ Cabbage $^{\mathrm{c}}$} & 0.895 & - & $31.43 \pm 0.66$ & 2.1 & - & $33.02 \pm 0.62$ & \\
\hline & & 100 & $130.79 \pm 1.85$ & 1.4 & 99.4 & $132.08 \pm 1.89$ & 99.1 \\
\hline \multirow[t]{2}{*}{ Apple } & 0.967 & - & $22.54 \pm 0.19$ & 0.8 & - & $23.12 \pm 0.20$ & \\
\hline & & 100 & $125.09 \pm 1.08$ & 0.9 & 102.5 & $124.79 \pm 1.11$ & 101.7 \\
\hline
\end{tabular}

a. Food samples were collected from the local market; the determined weight of a given food sample was subjected to the alkaline ashing step of the recommended procedure; the ash was treated, dissolved, and diluted in a $50-\mathrm{mL}$ calibrated flask and then the suitable volume was used for analysis. b. Total iodide concentration expressed in $\mu \mathrm{g} \mathrm{L}^{-1}\left(\right.$ or $\mu \mathrm{g} \mathrm{kg}^{-1}$ ); data are averages of five replicate determinations. c. Samples were dried in a thermostatted oven at $50^{\circ} \mathrm{C}$ to constant weight. 
Table 3 Comparison of the figures of merit for the proposed method with other methods

\begin{tabular}{|c|c|c|c|c|}
\hline Reaction system & $\begin{array}{l}\text { Determination range/ } \\
\mu \mathrm{g} \mathrm{L}^{-1}\end{array}$ & $\begin{array}{l}\text { Detection limit/ } \\
\qquad \mu \mathrm{g} \mathrm{L}{ }^{-1}\end{array}$ & Application & Ref. \\
\hline Variamine blue leucu base- $\mathrm{H}_{2} \mathrm{O}_{2}$ & NA & 21 & - & 17 \\
\hline Chlorpromazine- $\mathrm{BrO}_{3}^{-}$ & $5-70$ & 5 & Table salts, rate thyroid glands & 18 \\
\hline Pyrochatechol violet $-\mathrm{H}_{2} \mathrm{O}_{2}$ & $0-50$ & NA & Hot spring water & 19 \\
\hline [Co-EDTA] $-\mathrm{H}_{2} \mathrm{PO}_{2}-\mathrm{Pd}(\mathrm{II})$ & $2-28$ & 2 & Table salt, milk, pharmaceuticals & 20 \\
\hline Chlorpromazine- $\mathrm{H}_{2} \mathrm{O}_{2}$ & $0.2-10$ & 0.2 & River water & 21 \\
\hline $\mathrm{Ce}(\mathrm{IV})-\mathrm{As}(\mathrm{III})$ & $0-80$ & 1 & Waters, foods, biological samples & 22 \\
\hline Methyl violet- $\mathrm{IO}_{4}^{-}$ & $300-1400$ & 220 & Table salt & 23 \\
\hline Crystal violet- $\mathrm{IO}_{4}^{-}$ & $8-200$ & 3.8 & Table salt & 24 \\
\hline Bromopyrogallol red- $\mathrm{BrO}_{3}^{-}$ & $4.5-90$ & 4.5 & - & 25 \\
\hline Metanil yellow- $\mathrm{BrO}_{3}^{-}$ & $20-400$ & 15 & Laver, kelp, shrimp, table salt & 26 \\
\hline $\mathrm{NO}_{2}^{-}-[\mathrm{Fe}(\mathrm{SCN})]^{2+}$ & $0-100$ & 0.99 & Waters, foods, biological samples & 27 \\
\hline $\mathrm{Mn}(\mathrm{III})-\mathrm{As}(\mathrm{III})$ & $0.76-1.27$ & 0.76 & - & 28 \\
\hline Amaranath- $\mathrm{IO}_{4}^{-}$ & $0-20$ & 0.66 & Laver, shrimp, table salt & 29 \\
\hline Toulidine blue- $\mathrm{ClNH}_{3} \mathrm{OH}$ & $0-8$ & 0.4 & Laver, kelp, table salt, soybean & 30 \\
\hline$O$-Dianisidene-chloramine B & $0-0.004$ & 0.0004 & Natural waters & 31 \\
\hline Malachite green-chloramine $\mathrm{T}$ & $0-80$ & 1.6 & Laver, kelp & 32 \\
\hline Triupromazine- $\mathrm{H}_{2} \mathrm{O}_{2}$ & $0-4.5$ & 0.04 & Natural waters, food samples & 33 \\
\hline $\mathrm{Fe}^{3+}-\mathrm{SCN}^{-}-\mathrm{CP}^{+}-\mathrm{nBPy}$ & $5-120$ & 0.1 & Water samples & 34 \\
\hline MBDA-chloramine T & $0.1-6.0$ & 0.05 & Pharmaceutical products & 35 \\
\hline $\mathrm{I}^{-}-\mathrm{Br}_{2}$ & $20-3000$ & 8 & Synthetic samples of iodized salts & 36 \\
\hline $\mathrm{Ce}(\mathrm{IV})-\mathrm{As}(\mathrm{III})$ & $0.3-20.0$ & NA & Seaweed samples & 37 \\
\hline Rhodamine $\mathrm{B}-\mathrm{BrO}_{3}^{-}$ & $2.0-6.0,1.0-6.0$ & $0.06,0.07$ & Kelp & 38 \\
\hline Janus Green-BrO $3^{-}$ & $0.5-190.0$ & 0.12 & Food samples & This work \\
\hline
\end{tabular}

MBDA, 4,4-methylene bis( $N, N$-dimethylaniline). NA, Not available.

of the catalyzed reaction (three-times the standard deviation in $100.0 \mu \mathrm{g} \mathrm{L}^{-1}$ of iodide). Many foreign species did not interfere, even in a 1000-fold iodide. Sulfamic acid is an effective reagent for nitrite decomposition, which was used for this purpose. The addition of $2 \mathrm{~mL}$ of $3 \%$ sulfamic acid solution improved the interfering effect of nitrite to 1000 -fold. The interfering effect of some of cations was removed in the presence of $2 \mathrm{~mL}$ of a $2 \%$ EDTA solution. Chloride, bromide and vanadate ions had a seriously interfering effect.

\section{Application}

To evaluate the analytical applicability of the method, it was used for the determination of iodide in various food samples. Food samples were prepared according to the mentioned procedure. The results of the analysis of food samples by the proposed procedure and the standard method ${ }^{39}$ are given in Table 2. The recoveries were close to $100 \%$, which indicate there was no serious interference in such food samples. The $t$-test did not show any significant difference between the data obtained from the two methods (the 95\% confidence level and eight degrees of freedom). As given in Table 3, the method surpasses most kinetic methods ${ }^{17-38}$ for iodide determination in both the dynamic range and the detection limit. Therefore, the developed method is suitable for the analysis of food samples with satisfactory results.

\section{Conclusions}

The behavior of a selected system allowed the development of a kinetic method for the determination of trace amounts of iodide without any separation or preconcentration step. Hence, the use of organic solvents, which are generally toxic pollutants, is avoided. The proposed method is simple, sensitive and relatively selective compared with other methods. The procedure is suitable for the analysis of various food samples with satisfactory results.

\section{References}

1. E. J. Underwood, "Trace Elements in Human and Animal Nutrition", 1977, Academic Press, New York.

2. WHO, "Handbook of Nutritional Requirement", 1974, WHO, Geneva.

3. A. C. Pandey, Everymans Sci., 1986, 21, 1.

4. W. Clements, "Nutrition in Preventive", 1976, WHO, Geneva.

5. C. Guyton, "Text Book of Medical Physiology", 1986, W. B. Sanders, London.

6. K. A. Anderson and P. Markowski, J. Assoc. Off. Anal. Chem., 2000, 83, 225.

7. Y. Krengel-Rothensee, U. Richter, and P. Heitland, J. Anal. At. Spectrom., 1999, 14, 699.

8. L. F. Sanchez and J. Szpunar, J. Anal. At. Spectrom., 1999, 14, 1697.

9. E. H. Larsen, P. Knuthsen, and M. Hansen, J. Anal. At. Spectrom., 1999, 14, 41.

10. E. A. Arafa, F. H. Beshewa, A. I. Saleh, and H. A. Das, J. Trace. Microprobe Tech., 2000, 18, 137.

11. X. L. Hou, H. Dahlgaard, B. Rietz, U. Jacobsen, S. P. Nielsen, and A. Aarkrog, Anal. Chem., 1999, 71, 2745.

12. R. A. Niemann and D. L. Anderson, J. Chromatogr., A, 2008, 1200, 193.

13. T. Kimbeni Malongo, S. Patris, P. Macoursc, F. Cottona, J. Nsangub, and J. M. Kauffmanna, Talanta, 2008, 76, 540.

14. H. Jing, L. Li-Na, M. Shi-Fen, C. Ya-Qi, and L. Yi-Qiang, Chin. J. Anal. Chem., 2008, 36, 187.

15. M. D. Huang, H. Becker-Ross, S. Florek, M. Okruss, B. Welz, and S. Morés, Spectrochim. Acta, Part B, 2009, 
in press.

16. S. Rastegarzadeh, N. Pourreza, and I. Saeedi, Talanta, 2009, 77, 1032.

17. R. P. Igov, M. D. Jaredic, and T. G. Pecev, Mikrochim. Acta, 1979, 117, 271.

18. P. Vinas, M. Hernandez-Cordoba, and C. Sanchez-Pedreno, Talanta, 1987, 34, 351.

19. N. Yonehara, T. Yamane, T. Tomiyasu, and H. Sakamoto, Anal. Sci., 1989, 5, 175.

20. M. S. Garcia, C. Sanchez-Pedreno, I. Albero, and C. Sanchez, Analyst, 1991, 116, 653.

21. T. Tomiyasu, H. Sakamoto, and N. Yonehara, Anal. Sci., 1992, 8, 293.

22. J. L. Garwin, N. S. Rosenholtz, and A. Abdollahi, J. Food Sci., 1994, 59, 1135.

23. Z. X. Guo and S. Y. Zhang, Fenxi Shiyanshi, 1995, 14, 61.

24. Z. X. Guo, Y. Xiao, and S. Y. Zhang, Fenxi Shiyanshi, 1996, 15,32 .

25. S. Q. Wu, Fenxi Huaxue, 1996, 24, 24.

26. A. M. Zhang, H. S. Wang, H. Cui, and C. G. Fu, Fenxi Huaxue, 1996, 24, 689.

27. A. R. de-Araujo-Nogueira, F. Mockiuti, G. B. de-Souza, and O. Primavesi, Anal. Sci., 1998, 14, 559.

28. T. J. Pastor, G. A. Milovanovic, and G. M. Petkovic, Microchem. J., 1998, 60, 8.

29. A. M. Zhang and S. H.Wang, Fenxi Huaxue, 1998, 26, 967.
30. C. J. Lui and H. Zhang, Fenxi Huaxue, 1998, 26, 222.

31. O. P. Shkadauskene and Y. Shadauskas, Zh. Anal. Chem., 1999, 54, 158.

32. J. G. Li, Y. Qiao, and Y. Q. Wei, Fenxi Hиахие, 1999, 27, 1072.

33. A. A. Mohamed, Monatsh. Chem., 2001, 132, 919 .

34. A. Kamavisdar and R. M. Patel, Microchim. Acta, 2002, $140,119$.

35. Z. O. Tesfaldet, J. F. van Staden, and R. I. Stefan, Talanta, 2004, 64, 1213.

36. Z. Xie and J. Zhao, Talanta, 2004, 63, 339.

37. D. Gamallo-Lorenzo, M. C. Barciela-Alonso, A. Moreda Pineiro, A. Bermejo-Barrera, and P. Bermejo-Barrera, Anal. Chim. Acta, 2005, 542, 287.

38. X. Zhu and Y. Zhang, Spectrochim. Acta, Part A, 2008, 70, 510.

39. K. Helrich, "Offcial Methods of Analysis of the Association Offcial Analytical Chemists", 15th ed., 1990, AOAC, Arlington, VA.

40. R. E. D. Moxon and E. J. Dixon, Analyst, 1980, 105, 344.

41. S. Wang, L. Du, and A. Zhang, Chin. J. Anal. Chem., 2000, 28,628 .

42. S. Abbasi, M. Esfandyarpour, M. A. Taher, and A. Daneshfar, Spectrochim. Acta, Part A, 2007, 67, 578.

43. A. Safavi and R. Mirzajani, Anal. Sci., 2002, 18, 329. 